Jurnal Ilmu Sosial dan Pendidikan (JISIP)

Vol. 5 No. 3 Juli 2021

Terakreditasi Peringkat 5 (No. SK: 85/M/KPT/2020)

e-ISSN : 2656-6753, p-ISSN: 2598-9944

DOI: 10.36312/jisip.v5i3.2136/http://ejournal.mandalanursa.org/index.php/JISIP/index

\title{
Pertanggung Jawaban Tindak Pidana Korupsi Kredit Fiktif BNI Dengan Terdakwa Esron Napitupulu (putusan: No 1590 K/Pid. Sus/2015)
}

\author{
${ }^{1}$ Togu Aristo Sitorus, ${ }^{2}$ Eko Wahyu Roni, ${ }^{3}$ Theresia Simatupang \\ ${ }^{123}$ Fakultas Hukum, Universitas Prima Indonesia Medan \\ toguaristo@gmail.com,wwhyuc105@gmail.com, \\ simatupangtheresia99@gmail.com
}

\section{Article Info \\ Article history: \\ Article Received:June 222021 \\ Publised: July 102021}

\section{Keywords:}

liability, criminal acts, corruption,

fictitious credit.

\section{Article Info}

Article history:

Artikel diterima : Juni 222021

Publikasi : Juli 102021

\begin{abstract}
The purpose of this manuscript is first. To find out what is related to criminal answers to criminal acts of corruption that serve with fictitious credit based on the Law that stipulates answers to criminal acts of corruption. Second, to analyze Bank BNI's policies on fictitious corruption crimes. Third, to analyze the Judge's consideration to make a verdict on the accused of fictitious credit corruption in the Supreme Court Decision, No. 1590 K / Pid. Sus / 2015. The research method used by the author is in the perspective of legal philosophy, the values that influence the behavior of corruption crimes that are detrimental to state finances are used and normative legal research is used to find the truth of coherence in legal review, in principle, both legally written or unwritten. Based on the research results, based on the three problem formulations it can be rejected. First, what is the accountability of the fictitious credit corruption crime committed by the perpetrator. Second, what is the BNI policy towards the accused who has committed fictitious credit corruption by the perpetrator. Third, what are the judges' considerations in imposing (Supreme Court decision No. 1590K/ pid.sus (2015). Fictitious criminal acts of corruption must be carried out in accordance with the applicable legal provisions. Abstrak

Tujuan penulisan naskah ini yaitu pertama. Untuk mengetahui seperti apa pertanggung jawaban pidana terhadap tindak pidana korupsi yang dihubungkan dengan kredit fiktif berdasarkan Undang-undang yang sudah ditentukan tentang pertanggung jawaban tindak pidana korupsi. Kedua, untuk menganalisis Kebijakan Bank BNI terhadap terdakwa pelaku tindak pidana korupsi kredit fiktif. Ketiga, guna melakukan analisis pertimbangan Hakim untuk membuat putusan terhadap terdakwa pelaku Tindak pidana korupsi kredit fiktif dalam Putusan Mahkama Agung, No 1590 K/Pid. Sus/2015. Metode penelitian yang dipergunakan oleh penulis yaitu Dalam perspektif filsafat hukum akan dikaji mengenai nilai-nilai yang memengaruhi perilaku dari pelaku tindak pidana korupsi yang mengakibatkan kerugian keuangan Negara dan digunakan penelitian hukum normatif menemukan kebenaran koherensi dalam penelaahan hukum secara prinsip yang ada baik secara hukum tertulis maupun tidak tertulis. Berdasarkan hasil penelitian, berdasarkan tiga rumusan masalah dapat disimpulkan. Pertama, bagaimana pertanggung jawaban tindak pidana korupsi kredit fiktif tersebut yang dilakukan oleh pelaku. Kedua, Bagaimanakah kebijakan BNI terhadap terdakwa yang melakukan korupsi kredit fiktif yang dilakukan pelaku. Ketiga, Bagaimanakah pertimbangan hakim dalam menjatuhkan (putusan MA No. 1590K/pid.sus/2015).
\end{abstract}

This is an open access article under the Lisensi Creative Commons Atribusi-BerbagiSerupa 4.0 Internasional
Keywords:

pertanggung jawaban, tindak pidana, korupsi, kredit fiktif.

Corresponding Author:

Togu Aristo Sitorus

Fakultas Hukum, Universitas Prima Indonesia

Medan

Email: toguaristo@gmail.com 


\section{PENDAHULUAN \\ 1.1.Latar Belakang}

Pada umumya bank merupakan lembaga keuangan yang manfaatnya untuk memberi pinjaman, pendanaan layanan maupun keuangan lainya. Hal ini bank bertujuan untuk memberi layanan kebutuhan pendanaan serta mempermudah sistem pembayaran dalam bidang ekonomi.

Adanya bank sebagai penyedia layanan keuangan tidak luput dari masyarakat yang mengajukan pinjaman ataupun menabung uang. Dan sebagian besarnya bank adalah penyedia pembiayaan. Dalam hal ini bank memberikan pinjaman kepada nasabah yang pengembalianya dilakukan dengan mengangsur sesuai waktu yang telah di tentukan oleh pihak bank. Hal tersebut membuktikan bahwa upaya seorang individu dalam mencukupi kebutuhan dana finansialnya dengan melakukan pinjaman kepada bank. Tiap aktivitas yang dilakukan oleh bank wajib sejalan dengan ketaatan perbankan yaitu semua kegiatan perbankan yang di atur secara yuridis dalam UUD

Dengan adanya banyaknya aktivitas bisnis yang di laukan oleh bank, maka banyak peluang orang untuk memikirlkan atau merencakan bagaimana melanggar ketentuan ketentuan tersebut terhadap dunia perbankan. Seiring berjalanya waktu dan semakin banyaknya perkembangan teknologi dan pengetahuan manusia semakin besar pula tingkat kecurangan yang dilakukaanseseorang dalam upaya menguntungkan diri sendiri dalam melakukan modus pada bisnis perbankan ini. Kejahan yang sering dilakukan sesorang itu banyak berupa cara atau modus. Dan seiring berkembangnya dunia teknologi secara garis besar membuka peluang kejahatan dalam dunia perbankan

Penyalahgunaan kredit fiktif, kredit, pengurus atau pimpinan bank melarikan uang nasabah, pemalsuan giro atau tabungan, membentuk suatu bisnis perbankan tanpa ijin, membuat letter of credit palsu dan salah satunya adalah kejahatan kredit fiktif yang dilakukan oleh pegawai bank yang bekerjasama dengan nasabah untuk melakukan kejahatan korupsi kredit fiktif.

Dan modus yang terjadi dalam kejahatan kredit fiktif ini adalah dengan cara bekerjasama dengan pegawai bank atau orang dan ini adalah salah satu kejahan dengan cara penyuapan dan hal ini di atur dalam Undang- undang pada Pasal 8, Pasal 2, Pasal 29 butir (3), dan Pasal 49 butur (2) huruf a Undang-undang No. 10 Tahun 1998. Pada Pasal 49 butir (2) huruf a menyebutkan:

"Anggota direksi, dewan komisaris, maupun petugas bank yang secara sengaja menerima atau meminta, menyetujui atau memberi izin untuk menerima sebuah komisi, imbalan, pelayanan, uang tambahan, uang maupun barang berharga, untuk keuntungan pribadi maupun keluarganya, dengan maksdu memperoleh atau berusaha memperoleh bagi individu lain untuk mendapatkan bank garansi, uang muka, maupun fasilitas kredit dari bank, dan dengan maksud pendiskontoan atau pembelian oleh bank atas surat promes, cek, surat wesel, serta kertas dagang maupun bukti kewajiban lain, maupun dengan maksdu menyetujui untuk individu lain dalam menarik dana yang melebihi batas kreditnya pada bank, mendapat ancaman hukuman penjara setidaknya 3 (tiga) tahun dan maksimal 8 (delapan) tahun ataupun denda minimal Rp. 5.000.000.000,00 (lima miliar rupiah) dan maksimal Rp. 100.000.000.000,00 (seratus miliar rupiah)."

Pasal 263 butir (1) KUHP menjelaskan bahwa barang siapa memalsukan surat yang bisa mengakibatkan sebuah hak, pembebasan atau perikatan utang, maupun yang digunakan sebagai bukti sesuatu dengan tujuan menyuruh atau memakai orang lain dengan surat itu seolah-olah isinya benar atau tidak palsu, diberi ancaman jika penggunaan itubisa mengakibatkan kerugian, sebab pemalsuan surat, dengan hukuman kurungan paling lama 6 tahun. Pasal 263 butir (2) KUHP menerangkan mendapat ancaman dengan hukuman yang sama, siapapun secara sengaja menggunakan surat palsu seolah-olah asli, jikan penggunaan surat tersebut bisa mengakibatkan kerugian. 
Dan hendaknya pelaku kejahatan korupsi kredit fiktif ini harus mempertsanggung jaewabkan kejahatanya dan hal ini harus dilihat oleh public agar kejahatan ini tidak terjadi lagi dan menimbulkan rasa jera kepada pelaku kejahatn sehingga tidak meranggar moral yang ada dalam masyarakat Indonesia

Berdasarkan kejadian diatas maka penulis menuangkan atau menuagkan dalam tesis yang berjudul: PERTANGGUNG JAWABAN TINDAK PIDANA KORUPSI KREDIT FIKTIF BNI DENGAN TERDAKWA ESRON NAPITUPULUH.

\subsection{Rumusan Masalah}

1.Bagaimanakah pertanggung jawaban tindak pidana korupsi kredit fiktif?

2.Bagaimanakah kebijakan BNI terhadap terdakwa yang melakukan korupsi kredit fiktif?

3.Bagaimanakah pertimbangan hakim dalam menjatuhkan (putusan MA No. $1590 \mathrm{~K} /$ pid.sus/2015)

\subsection{Tujuan Penelitian}

1. Untuk menganalis pertanggungjawaban pelaku tindak pidana korupsi kredit fiktif dalam putusan Mahkama Agung, No 1590 K/Pid. Sus/2015.

2. Untuk menganalisis Kebijakan Bank BNI terhadap terdakwa pelaku tindak pidana korupsi kredit fiktif.

3. Untuk menganalisis pertimbangan Hakim untuk memberikan putusan terhadap terdakwa pelaku Tindak pidana korupsi kredit fiktif dalam Putusan Mahkama Agung, No 1590 K/Pid. Sus/2015.

\subsection{Mamfaat Penelitian}

Mamfaat penelitian dari penelitian ini adalah:

\section{Secara Teoritis}

Pembahasan yang dibuat pada diharapkan penelitian ini bisa menjadi pertimbangan dan bahan diskusi dan rujukan oleh mahasiswa dalam penulisan- penulisan yang terkait dalam Pertanggungjawaban Tindak pidana Korupsi kredit fiktif pada UU nomor 20 tahun 2001

\section{Secara Praktis}

Penelitiaan ini diharapkan bisa menjadi manfaat untuk Mahasiswa, masyarakat dan terlebih kepada pemerintah mengenai penegakan hukum tentang pertanggungjawaban tindak pidana korupsi kredit fiktif terhadap pelaku tindak pidana.

\section{KAJIAN PUSTAKA}

\subsection{Kerangka Teori}

a. Teori Pertanggung Jawabanpidana

Tindak Pidana Korupsi yaitu perbuatan yang bukan hanya bisa menyebabkan kerugian keuangan negara, namun juga bisa menyebabkan kerugian pada perekonomian rakyat. Barda Nawawi Arief menerangkan bahwa: Tindak Pidana Korupsi adalah tindakan yang sangat terkutuk, tercela, bahkan amat dibenci oleh banyak masyarakat tidak hanya oleh masyarakat Indonesia namun juga oleh masyarakat bangsa lain di dunia. Sehingga harus semestinya, sebagai bangsa yang mempunyai semangat dalam melahirkan kemakmuran secara adil dan merata dapat menghindari atau mengenali tiap bentuk korupsi yang hanya akan bisa menimbulkan kesengsaraan pada seluruh masyarakat Indonesia. Dengan mengenali bentuk korupsi, korupsi diharapkan sebagai musuh bersama yang perlu ditekan ataupun dihapus di seluruh wilayah Indonesia.

b. Teori Kepastian Hukum

Kepastian hukum amat di perlukan dalam menjamin ketentraman dalam masyarakat, sebab kepastian hukum (peraturan umum). Pernyataan yang ditegaskan didalam peraturan pasal 1 butir (3) UUD 1945. Sebagai konsekuensinya, tindakan tindakan atau perbuatan penguasa 
(pemerintah) ataupun lembaga lainnya termasuk warga masyarakat tunduk dan berlandaskan atas hukum dan dengan demikian hukum adalah peraturan tata tertib yang berlaku dalam masyarat, dimana hukum itu pada pelaksaanya bisa dipaksakan serta tujuannya memperoleh keadialan atau kepastian hukum.

c. Teori Keadilan

Menurut Institute Of Justinian kata Justice atau keadilan dirumuskan sebagai Justinice is the constant andcontinual purpose which given to everyone his own. Dengan demikian keadilan itu berbicara mengenai hak seseorang ketika diperhadapkan dengan apa yang mestinya diberikanya oleh orang yang memang menjadi haknya, apabila haktersebut tidak diterima maka dianggap tidak adil atau kurang adil.

Menurut Plato: Keadilan atau adil tidak berarti semua orang menerima dalam jumlah yang sama, tetapi keadilan menurut plato sebagai suatu yang dapat memberikan kebahagiaan, sebagaimana dapat dilihat dalanm tulisanya yaitu: bahwa keadialan sebenarnya sebagai masalah kesenangan yang tidak sama dan bahkan saling bertolakbelakang satu sama lai sehingga akhirnya keadilan hanyalah sesuatu untuk kompromi).

\subsection{Konsepsi}

\section{a. Pertanggungjawaban Tindak Pidana}

Adalah aproses penentuan orang yang melakukan perbuatan jahat bisa dihukum. Sebab apabila individu tidak bisa diminati pertanggungjawaban hukum, maka orang tersebut tidak bisa dihukum.

\section{b. Korupsi}

Korupsi asalnya dari bahasa latin corruption dari kata kerja corrumpera yang artinya rusak, busuk, menggoyahkan, memutar balik, menyogok yaitu perbuatan pejabat public, baik pegawai negri atau politisi, dan pihak lainnya yang bersangkutan pada tindakan tersebut yang dengan tidak wajar ataupun legal memanfaatkan kepercayaan public dengan salah yang diberikan pada mereka agar memperoleh laba pribadi.

\section{c. Kredit Fiktif}

Adalah sebuah perbuatan fraud di bidang kredit dari pihak intern (petugas) bank yang caranya dengan melakukan kongsi dengan nasabah pemohon kredit. Pada kredit fiktif surat yang diajukan ada akan namun nasabahnya tidak ada, hal tersebut diakibatkan pemohon kredit memakai identitas palsu maupun milik nasabah bank lainnya

\section{d. Bank}

Bank merupakan suatu lembaga intermediasi keuangan yang bisanya dibentuk dengan kekuasaan agar meminjamkan uang, menerima simpanan uang, serta melahirkan pr omaice yang disebut bank note.

\section{METODE PENELITIAN}

\subsection{Jenis Penelitiaan dan Pendekatan Masalah}

Penelitian ini merupakan penelitiaan hukum normative, sesuai dengan jenisnya sehingga penelitiaan ini menitikberatkan pada telaah hukumatau kajian hukum (rechts beofening) terhadap hukum positif. Dalam tataran dokmatika hukum dilakukan pada identifikasi beberapa peraturan perundan-undangan pidana, pada putusan hakim, khususnya yang terkait dengan tindak pidana korupsi. Dalam tataran teori hukum menganalisis beberapa teori yang bisa dipergunakan dalam menelaah permasalahan yang terkait dengan permasalahan yang dirumuskan dalam tulisan ini.

Dalam perspektif filsafat hukum akan dikaji mengenai nilai-nilai yang memengaruhi perilaku dari pelaku tindak pidana korupsi yang membuat rugi keuangan Negara dan masyarakat pada umumnya. Sebab dalam kenyataanya upuya pemusnahan tindak pidana korupsi sudah banyak dilakukan dengan beberapa cara, termasuk pembaharuaan perundang- 
undangan di bidang korupsi, tetapi justru ironinya perbuatan korupsi terus meningkat baik kuantitas ataupun kualitasnya.

Pendekatan undang-undang atau statute approach, dipergunakan karna yang diteliti yaitu aturan hukum yang terkait dengan perbuatan hukum korupsi. Pendekatan dibantu dengan menganalisis semua undang-undang yang berhubungan dengan tindak pidana korupsi, sehingga dalam pendekatan ini perlu memahami hierarki peraturan ataupun asas perundang-undangan. Pendekatan ini juga dipegunakan untiuk mendapat jawaban terhadap isu hukum yang dirumuiskan pada penelitiaan ini.

\subsection{Sumber dan Bahan Hukum}

Jenis penelitian ini merupakan penelitiaan hukum normative, dalam penelitiaan ini menggunakan bahan hukum:

1. Bahan Hukum Primer

Merupakan bahan hukum yang didapat dari undang-undang dimana bahan tersebut bersifat mengikat UU no. 31 tahun 1999 mengenai pemberantasan tindak pidana korupsi dan kredit fiktif Putusan Mahkamah Agung No 1590 K/Pid. Sus/2015.

2. Bahan Hukum Skunder

Merupakan bahan hukum yang sifatnya menerangkan bahan hukum primer, yang didapat dari perpustakaan ilmu hukum atau referensi lain. Oleh karena itu bahan hukum skunder ini terdiri atas buku buku atau referensi hukum, dan juga dilengkapi dengan berkas kasus perbuatan hukum korupsi yang sudah diputuskan oleh Mahkama Agung.

3. Sumber Bahan Hukum Tersier

Merupakan bahan hukum yang terdiri atas kamus dan ensiklopedia untuk menunjang bahan hukum sekunder maupun primer.

\subsection{Teknik Pengumpulan Data}

Metode pengumpulan data dalam penelitian ini dilakukan melalui setudi kepustakaan membaca, menelaah, serta membuat usulan-usulan dari bahan pustaka yang terkait dengan permasalahan yang adil dan teliti, serta melakukan setudi dokumen,membaca putusan yang menjadi panduan penelitian dari putusan Mahkamah Agung dan undang-undang yang bersangkutan dilakukan untuk memperoleh data yang bersifat notmative.

\subsubsection{Analisis Data}

Analisis data yang digunakan daam jurnal ini hakikatnya merupakan penalaran hukum, yaitu menggunakan metode dedukasi, indukdi, analogi, dan paraduksi secara simultan.

Tahap-tahap yang dilalui yaitu:

1. Perumusan Asas-asas hukum, baik dari data social atau bahan hukum positif

2. Perumusan beberapa definisi hukum

3. Membentuk standar hukum

4. Merumuskan kaidah hukum.

\section{PEMBAHASAN}

\subsection{Tindak Pidana Korupsi Kredit Fiktif BNI dengan Terdakwa Esron Napitupuluh}

\subsubsection{Kronologis Kasus}

Kasus ini berawal dari esron yang mengajukan kredit Rp40.000.00 Miliar ke 46 cabang BNI Pekanbaru oada tahun 2008 silam, sebagai agunan esron menyertakan surat-surat tanah di kabupaten Kmpar, Palalawan dan Kuangsing. Tanpa tinjauan dilapangan pegawai BNI bernama atok Dedy syaputra dan AB Manurung menytetujui kredit ini. Namum ternyata beberapa tanah yang diagunkan tidak ada, hal itu berdasarkan penyelidikan. 
Esron napitupuluh dan tiga pegawai BNI Atok Yudianto, ABC Manurung, dan Dedi Syahputra. Selain Dewi Farni Djaafar, Penyidik juga menetapkan seorang tersangka baru lainnya, yaitu Tengku Darmizon yang merupakan pegawai Badan Pertanahan Nasional (BPN) dimana yang dipidana dinyatakan berpartisipasi dalam menyetujui pemberian kredit 40.000.000.000 Miliyar kepada direktur pt riau barito jaya. Berawal pada 2007 selama Ahmat Fauzi menjadi pimpinan kantor wilayah 02 padang BNI 46 memberi persetujuan pengucuran dana kepada esron napitupuluh sebanyak Rp 17 miliar, pencairan oleh terdakwa ahamat fauzi ini menimbulkan kerugian Negara senilai Rp 14.445.000.000, sama seperti pencairan dana di tahun 2008 dpada masa pimpinan kantor Wilayah 02 BNI 46 dijabat Mulyawarman Muis yang selanjutnya menyebabkan kerugiaan Negara lagi senilai Rp 22.650.000.000. jumlah kerugian mencapai Rp 37 Miliyar.

\subsubsection{Dakwaan}

a. Primair, menggelar pasal 2 butir (1) no. Pasal 18 undang-undang republic Indonesia no. : 31 tahun 1999 mengenai pemberantasan tindak pidana korupsi yang sudah diamandemen dan ditambah dengan undang-undang RI no. : 20 tahun 2001 mengenai amandemen undang-undang RI No. : 31 tahun 1999 mengenai pemberantasan tindak pidana korupsi jo. Pasal 55ayat (1) ke-1 jo. Pasal 64 butir (1) KUHP.

b. b.Subsidair, melanggar pasal 1 angka1 UU RI No. : 19 tahun 2003 terkait badan usaha milik Negara.

\subsection{Kebijakan BNI terhadap terdakwa yang melakukan korupsi kredit fiktif}

4.2.1. Kebijakan Bank BNI

Pada dasarnya bank sebagi badan usaha yang mengupulkan uang dari masyarakat yang berbentuk simpanan, lalu disalurkan kepada masyarakat berbentuk kredit atau bentuk lain dengan maksdu mengembangkan perusahaan yang bergerak pada sektor keuangan, namun apa jadinya bila pegaiwai bank ikut andil dalam memuluskan kredit fiktif?

PT BNI sudah mempunyai presedur pengawasan internal guna menghindari kecurangan yang berlandaskan peraturan otoritas jasa keuangan (POJK) no 39/POJK.03/2019 mengenai pelaksanaan strategi anti fraud bagi bank umum.

Adapun jenis tindakan yang termasuk fraud adalah:

1. penipuan penggelapan asset

2. kecurangan

3. tindak pidana perbankan

4. pembocoran informasi

5. Perbuatann lainnya yang sama dengan fraud sesuai ketetapan peraturan undangundang.,disisi lain BNI juga memiliki kode etik, dalam kode etik tersebut pelanggaran sistem prosedur/kewajiban yang memiliki unsur kesengajaan serta mengakibatkan kerugian sanksinya adalah pemutusan hubungan kerja, oleh sebab itu karyawan yang telah melanggar kode etik yang mengandung kerugian dapat dilaporkan kepada pihak berwajib. Kita dapat megambil contoh dari kejadian esron napitupulu ini dimana ketiga terpidana yang turut memuluskan korupsi kredit fiktif esron napitupulu (Ab manurung, Atok yudianto dan Dedi syaputra) telah dilakukan pemutusan hubungan kerja dan juga pelaporan kepihak berwajib.

Jadi kita dapat mengambil kesimpulan bahwa pelanggaran kode etik dan juga korupsi kredit fiktif sanksinya adalah pemutusan hubungan kerja dan pelaporan ke pihak terkait

\subsection{Pertimbangan hakim dalam menjatuhkan (putusan MA No. 1590K/pid.sus/2015)}




\subsubsection{Pertimbagan hakim}

Mempertimbangkan, bahwa putusan Pengadilan Tinggi itu sudah diinformasikan kepada Penuntut Umum pada 07 April 2015 dan Jaksa mengusulkan permohonan kasasi pada 16 April 2015, memori kasasinya sudah diterima di Kepaniteraan Pengadilan Tindak Pidana Korupsi pada Pengadilan Negeri Pekanbaru pada 29 April 2015 sehingga permohonan kasasi dengan beberapa alasannya sudah diajukan dengan cara berlandaskan undang-undang dan dalam tenggang waktu, maka permohonan kasasi itu formal bisa diterima; Mempertimbangkan bahwa putusan Pengadilan Tinggi itu sudah disampaikan kepada Terdakwa pada 07 April 2015 serta Terdakwa membuat permohonan kasasi pada 13 April 2015, yang memori kasasinya sudah diterima di Kepaniteraan Pengadilan Tindak Pidana Korupsi pada Pengadilan Negeri Pekanabaru pada 27 April 2015 sehingga permohonan kasasi dengan alasannya sudah diberikan dalam tenggang waktu dan dengan cara berlandaskan undang-undang, maka permohonan kasasi tersebut formal bisa diterima;

Mempertimbangkan, bahwa alasan yang diberikan oleh para Pemohon Kasasi : Jaksa dan Terdakwa pada pokoknya yaitu: Alasan-alasan kasasi Jaksa: Bahwa Pengadilan Tindak Pidana Korupsi pada Pengadilan Tinggi Pekanbaru di Pekanbaru sudah membuat putusan dengan amarnya yang bunyinya seperti di atas pada pemeriksaan atau mengadili permasalahan itu dengan pertimbangan seperti berikut :

1. Bahwa Majelis Hakim dalam pertimbangannya memutus perkara tersebut sependapat ataupun mengambil alih baik pertimbangan hukum Majelis Hakim Tingkat Pertama maupun pertimbangan Jaksa/Penuntut Umum mengenai tindak pidana yang terbukti maupun status barang bukti namun tidak terhadap pemidanaannya.

2. Bahwa Majelis Hakim dalam pertimbangannya berdasarkan beberapa hal yang memberatkan menyatakan bahwa : - Tindakan Terdakwa tidak membantu program pemerintah dalam memberantas perbuatan hukum korupsi; - Tindakan Terdakwa suah menyebabkan kerugian keuangan Negara senilai Rp37.095.000.000,00 (tiga puluh tujuh miliar sembilan puluh lima juta rupiah). 2. Putusan Hakim

\section{MENGADILI}

Tidak menerima permohonan kasasi dari Pemohon Kasasi II/Terdakwa: ESRON NAPITUPULU tersebut; Tdak menerima permohonan kasasi dari Pemohon Kasasi I: JAKSA/ PENUNTUT UMUM PADA KEJAKSAAN NEGERI PEKANBARU tersebut; Memperbaiki putusan Pengadilan Tindak Pidana Korupsi pada Pengadilan Tinggi Pekanbaru No. : 05/PID.SUS-TPK/2015/PT.PBR tanggal 30 Maret 2015 yang memperbaiki putusan Pengadilan Tindak Pidana Korupsi pada Pengadilan Negeri PekanbaruNomor : 28/PID.SUS/TIPIKOR/ 2014/PN.PBR tanggal 16 Januari 2015;

\section{MENGADILI SENDIRI :}

1. Mengatakan Terdakwa ESRON NAPITUPULU telah terbukti secara sah dan meyakinkan bersalah melakukan perbuatan hukum "KORUPSI SECARA BERSAMA-SAMA DAN BERLANJUT";

2. Memberikan hukuman terhadap Terdakwa ESRON NAPITUPULU dengan humukan kurungan selama 8 (delapan) tahun dan denda senilai Rp200.000.000,00 (dua ratus juta rupiah), dengan peraturan jika denda tidak dibayar diganti dengan hukuman penjara selama 6 bulan;

3. Memberi hukuman pada Terdakwa ESRON NAPITUPULU agar membayar uang pengganti sebanyak Rp37.095.000.000,00, miliar dengan ketetapan bila 
Terdakwa tidak membayar uang pengganti tersebut, maksimal dalam waktu 1 bulan setelah perkaranya memperoleh putusan Pengadilan yang berkekuatan hukum tetap, maka harta bendanya akan disita oleh Jaksa ataupun dilelang guna membayar uang pengganti itu. Dalam hal Terdakwa tidak memiliki harta benda yang cukup guna menutupi uang pengganti tersebut, maka dihukum dengan pidana kurungan selama 3 (tiga) tahun;

4. Menentukan masa tahanan yang sudah dijalani oleh Terdakwa dikurangkan semuanya dari hukuman yang diberikan;

5. Menetapkan agar Terdakwa tetap ditahan;

6. Menetapkan barang bukti berupa:

- Surat Keterangan Tanah (SKT) Desa Sako Margasari, Kabupaten Kuansing sebanyak 500 (lima ratus) persil

- Surat Keterangan Riwayat Pemilikan/Penguasaan Tanah (SKRPT) Desa Pasir Mas, Kabupaten Kuansing sebanyak 146 (seratus empat puluh enam ) persi

- Tanah seluas 315 M2 (tiga ratus lima belas meter persegi) berikut 1 unit bangunan rumah permanen 1 (satu) lantai dengan luas 180 M2 (seratus delapan puluh meter persegi).

- Tanah seluas 440 M2 (empat ratus empat puluh meter persegi) berikut 1 unit bangunan rumah permanen 2 (dua) lantai dengan luas 509,63 M (lima ratus sembilan koma enam puluh tiga meter persegi)

\subsection{Analisis Kasus}

Putusan Mahkama Agung saat mempelajari dan memeriksa berkas dan beberapa surat yang terkait dengan permasalahan, dibawah ini turunan putusan Mahkama Agung nomor $1590 \mathrm{~K} / \mathrm{Pid}$. Sus/2015 tanggal 30 Juli 2015 dan bukti surat lainnya yang berkaitan, memberikan pendapat bahwa pertimbangan hukum Mahkma Agung yang melandasi putusannya tentang sudah terbuktinya secara sah ataupun meyakinkan kesalahan Terdakwa "berbuat tindak pidana dengan sengaja melakukan korupsi kredit fiktif " menggelar pasal 2 junto pasal 18 undang-undang RI No. 31 tahun 1999 mengenai tindak pidana korupsi, sebagaimana dalam dakwaan Penuntut Umum serta lamanya hukuman yang diberikan sudah benar ataupun tepat. Menjatuhkan beban biaya permasalahan kepada Terdakwa sejumlah Rp 2.500,00,--

\section{KESIMPULAN}

1. Faktor-faktot terjadinya Tindak Pidana Korupsi Kredit Fiktif adalah sebagai berikut:

a. Adanya keiginan ingin kaya atau mempunyai harta berlimpah.

b. Adanya rasa ketidak puasan atas apa yang dimiliki atau ingin lagi dan lagi.

c. Adanya factor dari internal dari pihak bank yang memberikan peluang bagi nasabah untuk menlakukan pinjaman tanpa adanya bukti atau jaminan yang pasti.

d. Kerjasama antara pihak atau pegawai bank dengan nasabah untuk memuluskan tindak pidana kredit fiktif.

e. Ketidak jelian pegawaai bank dalam pemeriksaan jaminan hutang yang lengkap.

f. Ketidak adilan pemerintah apabila kasus yang sama terjadi, pemerintah kurang menegakkan hukum dalam penanganan kasus perbuatan hukum korupsi, sehingga tidak menyebabkan efek jera kepada sipelaku maupun terdakwa.

2. Dengan adanya badan usaha yang mengumpulkan biaya dari masyarakat berupa simpanan, lalu disalurkan dalam bentuk kredit ini merupakan jalan atau cara dari pegawai bank melakukan kecurangan untuk kepentigan pribadi atau organisasi tertentu baik itu penipuan penggelapan asset, pembocoran informasi, perbuatan kecurangan, perbuatan kejahatan perbankan ataupun 
tindak lainya salah satunya adalah dengan melakukan kredit fiktif yang dilakukan oleh esron napitupuluh oleh karena itu BNI melakukan prosedur pengawasan internal dalam menghindari kecurangan yang berlandaskan peraturan otoritas jasa keuangan (OJK), agar tidak adalagi kasus yang sama.

3. Fakta yang terungkap dalam persidangan adalah Esron Napitupuluh sudah dinyatakan sebagai pelaku yang melakukan tindak pidana korupsi kredit fiktif dan di jatuhi hukuman sesuai yang tertera pada putusan MA No $1590 \mathrm{~K} / \mathrm{Pid}$. Sus/2015.

Karena sudah terbukti "Dengan Sengaja Melakukan Tindak Pidana Kredit Fiktif Di Bank Nasiomal Indonesia (BNI)" yang melanggar Pasal 2junto Pasal 18 Undang-Undang RI No.31 Tahun 1999 mengenai tindak pidana korupsi maka terdakwa Esron Napitupulu dipenjara selama 6 tahun kurungan penjara dan denda Rp400.000.000,- , selama 3 bulan, dan diwajibkan membayar uang pengganti kerugian negara sebesar Rp37.095.000.000 miliar selama tiga tahun.

\section{SARAN}

1. Diharapkan kepada pemerintah dalam penangan kasus Tindak Pidana Korupsi Kredit Fiktif harus lebih maksimal dalam penangan dan penjatuhan hukum, supaya ada efek jera.

2. Perlunya kesadaran bagi masyarakat supaya memenuhi syarat peminjaman tanpa ada maksut tertentu atau ingin melakukan korupsi.

3. Taatlah kepada Hukum yang berlaku dan norma yang ber;aku di pemerintahan.

\section{DAFTAR PUSTAKA}

\section{Buku}

Evi Hartanti, “Tinddak Pidana Korupsi edisi II”, Sinar Grafika Terbit, Jakarta, 2019, hal. 5

Evi Hartanti, Tinddak Pidana Korupsi edisi II, Sinar Grafika Terbit, Jakarta, 2019

Frilly Margaret Wuragian, "Pertanggungjawaban pidana Terhadap Korupsi Perbankan Akibat Dari Tindak Pembobolan Bank”, Lex Crimen Vol IV.

Jawada hafids, "Sistem Pertanggungjawaban Perkara Korupsi Dalam Rangka Percepatan Penyelamatan Uang Negar"a. Semarang. 124 Jurnal Dinamika Hukum.

Prayetno Iman Santosa, "Pertanggungjawaban Tindak Pidana Korupsi", PT Alumni Terbit, Bandung, 2015, hal.76

Prayetno Iman Santosa, "Pertanggungjawaban Tindak Pidana Korupsi”, PT Alumni Terbit, Bandung, 2015, hal.42.

Prayetno Iman Santosa, "Pertanggungjawaban Tindak Pidana Korupsi", PT Alumni Terbit, Bandung, 2015, hal.76

Regita Dilla Chintya, "Pertanggungjawaban Pidana Debitur Dalam Kasus Kredit Macet", Palembang, Jurnal Dinamika Hukum.

Rony Syahputra, "Pertanggungjawaban Pidana Korporasi Dalam Tindak Pidana Korups" $i$, Padang, 270 Jurnal Cita Hukum.

\section{Peraturan Perundangg-undangan}

Undang-Undang No. 31 Tahun 1999 Terkait Pemberantasan Tindak Pidana Korupsi

Undang-Undang Nomor 21Tahun 2011 mengenai Otoritas Jasa Keuangan

Internet

https://www.bni.co.id/id.id/perusahaan/tatakelola/kodeetik 